\title{
Blended teaching and learning methods in nursing and midwifery education: A scoping review of the literature
}

\author{
*Ndayisenga, J.P. ${ }^{1,2,3}$, Babenko-Mould, Y. ${ }^{2}$, Kasine, $\mathbf{Y}_{.2}^{,}$, Nkurunziza, A. ${ }^{1,2}$, \\ Mukamana, D. ${ }^{1}$, Murekezi, J.,4, Tengera, O.,3, Muhayimana, A.,
}

\begin{abstract}
Background: Blended learning (BL) is defined as the combination of both traditional face-to-face learning and synchronous or asynchronous e-learning approaches. The aim of this scoping review was to explore the literature to obtain a broad understanding of the use of BL in nursing and midwifery education in general, in Sub-Saharan Africa (SSA), and in particular Rwanda.
\end{abstract}

Methods: The literature published between 2010 and 2019 were reviewed from six electronic databases using keywords including blended learning, nursing education, midwifery education, higher education, SSA, and Rwanda. Arksey and O'Malley's framework was used in this review.

Results: The initial search identified 1,283 records. Eleven articles were selected for this review after the application of predetermined inclusion criteria. Almost all reviewed articles indicated that the integration of BL methods improved the quality of nursing and midwifery education in general, and in SSA countries including Rwanda.

Conclusions: Initial research in this area highlights that moving from traditional classroom-delivered programs to the BL approach is feasible and can promote the quality of nursing and midwifery standards of education. This scoping review highlights a paucity of research on BL in nursing and midwifery education, particularly in SSA countries.

Keywords: Blended learning, nursing and midwifery education, SSA, Rwanda

*Corresponding author

Ndayisenga, J.P.

ORCID -ID: http://orcid.org/0000-0002-3508-975X

Email:jndayise@uwo.ca

'School of Nursing and Midwifery, University of Rwanda, Kigali, Rwanda

${ }^{2}$ Arthur Labatt Family School of Nursing, Western University, London, Canada

${ }^{3}$ Rwanda Association of Midwives, Kigali, Rwanda

${ }^{4}$ King Faisal Hospital, Kigali, Rwanda 


\title{
Enseignement mélangé et méthodes d'apprentissage dans l'enseignement des soins infirmiers et obstétricaux: Un examen de la portée de la littérature
}

\author{
*Ndayisenga, J.P. ${ }^{1,2,3}$, Babenko-Mould, Y. ${ }^{2}$, Kasine, Y. $^{, 2}$, Nkurunziza, A. ${ }^{1,2}$, \\ Mukamana, D. ${ }^{1}$, Murekezi, J., ${ }^{3,4}$ Tengera, O. $^{1,3}$, Muhayimana, A. ${ }^{1,3}$
}

\section{Résumé}

Contexte général de l'étude : L'apprentissage mixte (AM) est défini comme la combinaison de l'apprentissage traditionnel en face à face et d'approches d'apprentissage en ligne synchrones ou asynchrones. L'objectif de cette étude exploratoire était d'explorer la littérature pour obtenir une large compréhension au de l'utilisation de BL dans l'enseignement des soins infirmiers et obstétricaux en général, en Afrique subsaharienne (ASS), et en particulier au Rwanda.

Méthode de l'étude: La littérature publiée entre 2010 et 2019 a été examinée à partir de six bases de données électroniques utilisant des mots-clés comprenant l'apprentissage mixte, l'enseignement infirmier, l'enseignement des sages-femmes, l'enseignement supérieur, l'ASS et le Rwanda. Le cadre d'Arksey et O'Malley a été utilisé dans cette revue.

Résultat de l'étude: La recherche initiale a identifié 1283 enregistrements. Onze articles ont été sélectionnés pour cette revue après l'application de critères d'inclusion prédéterminés. Presque tous les articles examinés ont indiqué que l'intégration des méthodes BL a amélioré la qualité de la formation infirmière et obstétricale en général, et dans les pays de l'ASS, y compris le Rwanda.

Conclusion: La recherche initiale dans ce domaine met en évidence que le passage des programmes traditionnels dispensés en classe à l'approche BL est faisable et peut promouvoir la qualité des normes d'éducation infirmière et obstétricale. Cet examen de la portée met en évidence un manque de recherche sur la BL dans la formation des infirmières et des sages-femmes, en particulier dans les pays d'Afrique subsaharienne.

Mots-clés: Apprentissage mixte, formation en soins infirmiers et obstétricaux, ASS, Rwanda

*Corresponding author

Ndayisenga, J.P.

ORCID -ID: http://orcid.org/0000-0002-3508-975X

Email:jndayise@uwo.ca

\footnotetext{
'School of Nursing and Midwifery, University of Rwanda, Kigali, Rwanda

${ }^{2}$ Arthur Labatt Family School of Nursing, Western University, London, Canada

${ }^{3}$ Rwanda Association of Midwives, Kigali, Rwanda

${ }^{4}$ King Faisal Hospital, Kigali, Rwanda
} 


\section{INTRODUCTION}

Educators in nursing and midwifery education programs are charged with preparing students to be able to practice in a variety of settings where they must apply advanced reasoning, judgment, and problem-solving skills in a knowledgeable manner to support patient health and well-being $(1,2)$. Advancements in the use of technology have become integral to everyday life among the current generation of university students (3). This has created opportunities for educators to use technology in health education programs to facilitate students' learning in dynamic and interactive ways that can complement more traditional classroom contexts. Given the increased pressure and demand for both educators and students in nursing and midwifery undergraduate and graduate programs to undertake changes in teaching and learning approaches, education needs to be delivered in ways that promote and meet the conceptual needs of students' and of faculty's time (4). Such changes mean that nursing and midwifery schools must adopt different teaching and learning methods while maintaining excellence in nursing and midwifery education. Some of these different teaching and learning methods include electronic learning (elearning), web-based or online teaching and learning, and blended learning (BL).

E-learning is defined as an educational system in which learners and educators are physically separated by the environment but linked together with the help of technology, teaching tools, and equipment (5). These methods shift teaching and learning from a largely product-based activity and teacher-centered learning to more process-based and studentcentered activities (3). Another added value of these methods is to encourage students to be more active rather than being passive learners $(3,6,7)$. In nursing and midwifery education, the use of elearning promotes self-directed learning among learners and can be an alternative solution to the shortage of nursing and midwifery faculty $(6,8,9)$. For instance, during the COVID-19 pandemic period where most students were not attending face-to-face classes, the e-learning method was used as an alternative solution that minimized risks of contamination while doors of learning were still open to all learners.

Although e-learning has its own advantages and benefits, it also has limitations and challenges particularly in SSA countries like Rwanda where academic resources are limited. That is the reason why e-learning cannot replace a teacher, in-person interaction, and traditional methods like the face-to-face classroom $(6,10,11)$. Some of these challenges and limitations include problems with technology such as limited computer skills, limited internet access, low start rates and high dropout rates of students, and lack of oversight among the elearning users $(12,13)$. In SSA, apart from the technical-related challenges, most of the universities are also in crisis and rely on foreign donors to fund higher education and even the infrastructure of some schools is in a state of collapse (14). In Rwanda, for instance, there are e-learning programs in nursing and midwifery education but not all faculty are well prepared to efficiently teach the courses or use the technology in ways that enable the facilitation of teaching methods to support optimal learning (15).

To gather the best of both e-learning and traditional classroom teaching and learning environments, researchers are suggesting a new teaching environment: blended learning (BL). BL approach combines both e-learning and faceto-face teaching and learning methods. In order to provide and promote the best teaching and learning environment for faculty and students and to reduce some costs related to other teaching methods, nursing and midwifery teaching institutions have started adopting $\mathrm{BL}(4,16)$.

Blended learning is defined as the combination of both traditional face-to-face learning and synchronous or asynchronous elearning approaches $(16,17)$. In high-income countries, BL has become one of the popular approaches in undergraduate and graduate nursing and midwifery education. Increased access to the internet and faster internet speed have enabled the potential of BL to be achieved $(10,13,18)$. However, in low-income countries such as SSA where Rwanda is located, the use of $\mathrm{BL}$ approach is still facing a big challenge such as lack of infrastructure facilities including internet connection and computers in most of the universities (14).

The most common benefits of using BL include the effective use of time, updated teaching and learning materials, continuous learning, and reducing transportation costs for learners and educators $(15,17)$. In addition, the BL environment gives nursing and midwifery students more advantages than face-to-face teaching and e-learning environments alone where learners interact with course facilitators, as well as enjoying the flexibility and other advantages that are provided by e-learning approaches. Studies suggest that the use of BL 
can help to decrease the dropout rate in higher education and improve students' performance $(6,18)$. Moreover, BL methods facilitate nursing and midwifery faculty to find the best ways to better engage and involve students by using online resources and materials they are already familiar with $(6,12,19)$.

Within the literature, there is increasing evidence about the benefits of BL such as improving students' academic performance in classrooms and clinical practice, producing equal or better outcomes compared to traditional teaching and learning methods in health education and clinical disciplines. Students had been noted to prefer BL which facilitates resource sharing among learners in academia and promotes the effective use of time by both students and faculty members $(12,16,22)$. Like developed countries, nursing and midwifery teaching institutions in SSA countries including Rwanda is moving more toward the wide adoption of the BL method (9,19-21). Given the burgeoning use of $\mathrm{BL}$, it is important to conduct this scoping review in order to obtain a broad understanding about the use of BL in nursing and midwifery education in general, Sub-Saharan African countries, and particularly in Rwanda. By doing so, gaps in the literature may be identified to support future studies about BL in nursing and midwifery education. In addition, this can help in the improvement of online education during COVID 19 crisis.

\section{MATERIALSAND METHODS}

This scoping review was guided by Arksey and O'Malley's (23) framework. Arksey and O'Malley's (23) framework provides a method for the scoping review in which the authors included reviewed articles, non-research articles, and grey literature. Arksey and O'Malley (23) suggest the five steps of scoping reviews to include: (1) identification of the research question(s) to be addressed, (2) identification of studies relevant to the research question(s), (3) selection of the studies to include in the review, (4) charting of data and information within the included studies, and (5) collating, summarizing and reporting the results of the review.

\section{Identifying the Research Questions}

The following research questions guided the first step of the scoping review: What is known from the existing literature about BL in nursing and midwifery education in general, in SSA, and in Rwanda? What research gaps exist about BL in nursing and midwifery education?

\section{Identifying Relevant Studies}

The second step included the identification of relevant articles related to the research questions through different databases. There was adoption of a wide definition of keywords for search terms. Multiple database searches were conducted to locate all related articles. Web-based searches, electronic databases, and reference lists written in the English language were used to retrieve existing literature about BL. In addition, the sequencing of keywords combinations was used. The list of key search words can be found in Table 1. In this scoping review, the search focused on articles written in English. The search years were limited to articles published from 2010 to 2019 in order to include to include the most current literature. To ensure that only relevant literature related to the research questions was included, the search was also limited to nursing and midwifery education.

The literature search was conducted using the following six electronic databases: MEDLINE, Cumulative Index to Nursing and Allied Health Literature (CINAHL), Psych INFO, Scopus, Nursing and Allied Health Database, and ProQuest. In addition, Google Scholar was used to identify any other primary sources within the grey literature. To ensure that all relevant data was accessed, the databases were searched multiple times over a period of six months.

\section{Selection of Studies}

The third step of this scoping literature review involved the selection of studies. Inclusion and exclusion criteria were set to help eliminate articles which were not pertinent to the research questions. Initially, titles and abstracts of retrieved articles were screened based on the pre-established inclusion criteria, then the reviewer continued the screening based on the eligibility of the full texts by reading the whole content of the articles (Table. 2). Figure 1 describes the study selection process.

\section{Charting the Data}

The fourth stage involved charting the data. According to Armstrong and colluegues (24), charting of data is used to identify themes and commonalities, which focus on the identified scoping research questions. Summaries of selected articles' results (Table 3) were developed based on the following information: author, year, purpose of the study, study methods, location of the study, findings, and conclusion of the study. In addition, the reviewers provided a brief summary 
comment on the limitations and recommendations of each selected study (Table 3 ). The results of this scoping review are reported in a narrative form emphasizing the identified themes associated with BL in nursing and midwifery education that emerged from the literature (25)

\section{Summarizing and Reporting the Results of the Review}

In the scoping literature review, the fifth stage involved summarizing and reporting the results or findings of the review. Results of this review are summarized in Table 3:

\section{RESULTS}

Using the key search descriptors, 1,283 potential articles were identified through the selected databases. Following de-duplication references, 1,037 articles were screened (See Figure.1). Following title screening, 88 articles $(8.5 \%)$ were included for abstract screening. To select the articles that are relevant to the scoping review questions, abstracts were read and analyzed. Of the 88 articles, 26 articles $(2.5 \%)$ had themes related to $\mathrm{BL}$ in nursing and midwifery education in general and SSA, and Rwanda specifically. Again, the 26 articles were selected by the authors for full text analysis based on the added inclusion and exclusion criteria (Table 2), and 11 of the 26 articles were selected for full scoping review (See Figure.1: Flow diagram of scoping review process). The main reasons for article exclusion were that the population studied were not nurses or midwives, the context of the study was not specifically focused on nursing or midwifery, or the outcome measured or reported was not related to BL or related to nursing and midwifery education.

This scoping review included eleven eligible articles related-to BL method in nursing and midwifery education from nine countries. Of these; three studies were conducted in the United Kingdom $(6,26,35)$, one in the United States (17), one in Australia (28), one in Sweden (32), one in Iran (21), and one in India (8). Moreover, this review included three studies conducted in the SSA countries including Ghana, South Africa, and Rwanda $(15,29,33)$.

\section{Characteristics and Structure of BL Programs in Nursing and Midwifery Education}

This scoping review revealed that the BL approach has been used more extensively in both undergraduate and graduate nursing and midwifery programs. Some programs use short time online or e-learning to supplement the materials discussed in the classroom or face-toface environment $(17,21,29,33)$. Other programs incorporate BL by using short time face-to-face discussion and then students spend the rest of their learning time completing online asynchronous or synchronous course activities working independently $(8,15,26,32)$.

In SSA countries like Rwanda (15), Ghana (33), and South Africa (36), BL in nursing and midwifery education covers a wide range of teaching and learning activities between elearning and traditional face-to-face interactions $(15,33,36)$. The reviewed studies identified three modes of BL used in SSA nursing and midwifery programs. The convergent triangulated mixed methods study done by Harerimana and collegues (15) in Rwanda indicated that to implement BL programs, technology was used to enhance nursing and midwifery management and to provide resources to students through a University Moodle web site. Additionally, in Ghana (33) and South Africa (29), technologies were used in BL to enrich the quality of nursing and midwifery students' learning experiences like face-to-face classroom interactions, online assessments, collaborations and case studies. Moreover, technology was used in Rwandan nursing education to support students and faculty in teaching and learning that is largely selfdirected and involves the use of collaborative and interactive learning activities (15).

\section{Quality of Nursing and Midwifery Education as a Result of $B L$}

Almost all of the reviewed articles indicated that the integration of BL methods support delivery of quality nursing and midwifery education in general and in SSA countries, including Rwanda $(8,15,36)$. The use of blended teaching and learning methods resulted in higher level of nursing and midwifery students performances and skills (28), improved students satisfaction with course content, technologies used and social interactions among learners $(17,28)$, promoted student centered teaching and learning opportunities and improve significantly students' performance $(27,30,37)$.

Harerimana and colleagues (15) conducted a convergent mixed method study with triangulation study in Rwanda to evaluate the utilization of e-learning in the selected nursing programs. In their study (30), they found that BL is a more flexible approach as it gave students more chances of searching updated information and engaged students with open discussion at a 
convenient time for BL participations. This author reported that $\mathrm{BL}$ helped the students to become more familiar with technology in both asynchronous and synchronous approaches (Table 3).

Most of all researchers were supportive of the integration of BL methods in nursing and midwifery education in general (Table.3), with one researcher reporting that there has not yet been enough research conducted about the implementation of BL to support an overall decision of its effectiveness as a teachinglearning method (6). In SSA countries like Ghana, South Africa and Rwanda, researchers reported that BL programs were effective in the transformation of nursing and midwifery profession in different ways $(6,30,33)$. The use of $\mathrm{BL}$ in education of nurses and midwives played an important role to improve the quality of care delivery (15).

\section{Identified Gaps about BL in Nursing and Midwifery Education}

This scoping review highlighted a particular scarcity in the studies conducted about the use of BL in nursing and midwifery education in SSA countries including Rwanda. In some studies, the term BL was used in place of terms such as, e-learning, web-based, online education, computer assisted learning, and technology enhanced learning $(17,29,30,34)$

\section{DISCUSSION}

Overall, authors of reviewed studies noted that BL methods can support the delivery of quality nursing and midwifery education, especially in SSA countries including Rwanda where higher education is still facing the shortage of faculty members, but where rapid technological advancements are enabling students to access education programs and resources. Based on the reviewed studies, the benefits and features of using BL methods in nursing and midwifery education are discussed below.

\section{Benefits of BL}

The findings of this scoping review outline that effective use of BL approaches can support delivery of quality nursing and midwifery education in general, in SSA and in Rwanda. Atef and Medhat (38) stated that BL holds a particular future promise for developing countries because it can increase the availability and wide access to different types teaching and learning resources available worldwide and could promote collaboration between teaching and learning among health professionals globally. Protsiv and colleagues (9) concluded that $\mathrm{BL}$ is an effective and feasible approach to simultaneously draw upon available global knowledge and skills into cross-national, highlevel teaching and learning in multiple countries. Indeed, in SSA countries including Rwanda, BL is considered an excellent teaching and learning approach $(9,30,38,39)$. The causal-comparative study conducted in the United States concluded that there was no statistical difference in terms of academic performance before and after the course adopted BL in nursing students (17). However, different studies have found that a well-designed BL approach for a course or program addresses more teaching and learning style requirements and can increase students' performance or positive learning outcomes $(33,34,38)$. While different studies have found that the BL approach is commonly used in health professional education $(3,6,16)$, this review suggests that more studies need to be conducted to increase the evidence about the use of BL in nursing and midwifery in SSA as well as in Rwanda. The reviewers proposed that qualitative studies involving nursing and midwifery students and educators could bring new ideas of how BL could contribute to nursing and midwifery education in SSA and in Rwanda.

\section{Features of Successful BLApproaches}

This scoping review of the literature provided insight in terms of structure of $\mathrm{BL}$ approach in nursing and midwifery education. Desirable features of effective and successful BL program depends on learners' characteristics and backgrounds such as student motivation, social and family support, computer competencies, workload management, and attitudes to $\mathrm{BL}$ $(17,28,37)$. In addition, BL in program effectiveness may be dependent on other factors like competent educators with computer skills, conducive BL environments, and well-designed web materials $(30,33,34)$.

The results of this review demonstrated that the effectiveness of BL depends on students' interactions with course facilitators since failure to continue with online learning is attributed to this. The findings of this review highlight the need of supporting the use of BL in SSA countries for nursing and midwifery students from all areas in web-based programs and this may be from course facilitators, friends, family, peers in the programs, and co-workers. For example, in Rwanda, Harerimana and colleagues (30) found 
that $\mathrm{BL}$ in nursing programs need to have competent educators with the technological skills to assist the students in their learning activities. Moreover, Harerimana and colleagues (30) suggested that establishing BL policies can provide a clear guidance and the direction of future nursing and midwifery development.

\section{Further Research}

This scoping review identified limited studies investigating $\mathrm{BL}$ as an approach to improve the quality and the standards of nursing and midwifery in general. To improve the integration of $\mathrm{BL}$ and the evidence-based data and information on this topic for nursing and midwifery education in SSA countries as well as in Rwanda, it is vital to conduct more research on $\mathrm{BL}$ to clearly evaluate the effectiveness of different models of BL in the context of SSA countries. In addition, to gain a clear understanding about the challenges associated with the use BL, there is a need for qualitative studies in SSA as well as in Rwanda to explore the experiences of both educators and or students in use of $\mathrm{BL}$ in their respective institutions. Moreover, to investigate how BL improves teaching and learning in nursing and midwifery education in SSA experimental designs are needed in future studies.

Limitations: This scoping review of the literature sought to identify existing evidence and resources that are available about the phenomenon of interest and identify research gaps. While the evidence of BL in nursing and midwifery education particularly in SSA countries was limited or almost not exist, this becomes a limitation of this scoping review. Also, some reviewed articles have considered elearning as BL. This shows how some results were not clear about the outcomes related to BL. In addition, only English language articles were considered for inclusion in this study. As such, this review did not include possibly relevant articles published in non-English speaking countries written in other languages. Moreover, the review searched for articles published from 2010, so other studies published before this date were not included.

\section{CONCLUSION}

In the reviewed studies in this paper, it was observed that BL integrated in nursing and midwifery education was perceived as useful, supportive, enjoyable, flexible and a motivator for students to engage in learning. However, BL methods in nursing and midwifery education are minimally documented in the literature. This scoping review highlights a paucity of research on BL in nursing and midwifery education, particularly in SSA countries and in Rwanda. The existing literature highlighted that moving from traditional classroom-delivered program to a $\mathrm{BL}$ approach is feasible and can promote the quality of nursing and midwifery education. However, in SSA countries such as Rwanda is located, the use of BL methods is still facing challenges of broadly effective implementation due to issues around infrastructure such as internet and computer access either in educational or home settings.

In general, there is an absolute need of the future research studies on the use designs of $\mathrm{BL}$ innovations using different research methodologies to overcome the existing gap in the area of BL in nursing and midwifery education, especially in SSA countries. The studies reviewed in this scoping review reported that successful BL approaches depend on learners' characteristics and backgrounds such as self-regulation, social and family support, computer competencies, workload management, attitudes to blended learning. Other factors that contribute to successful BL program include design features, competent educators and conducive BL environment. In addition, the findings from this scoping review highlighted the need of supporting the use of blended teaching and learning in SSA countries for nursing and midwifery education program and the support may be from obtained course facilitators, friends, family, peers in the programs, and co-workers.

Acknowledgement: The researchers are grateful to the United Nations Population Fund (UNFPA) Rwanda for the support received from them in carrying out this research.

Conflicts of interest: The Authors declare that there is no conflict of interest.

\section{REFERENCES}

1. Fukada M. Nursing competency: Definition, structure and development. Yonago Acta Medica. 2018.

2. Leung K, Trevena L, Waters D. Development of a competency framework for evidence-based practice in nursing. Nurse Educ Today. 2016;

3. Makhdoom N, Khoshhal KI, Algaidi S, Heissam $\mathrm{K}$, Zolaly MA. "Blended learning" as an effective teaching and learning strategy in clinical medicine: A comparative cross-sectional university-based study. J Taibah Univ Med Sci 
[Internet]. 2013;8(1):12-7. Available from: http://dx.doi.org/10.1016/j.jtumed.2013.01.002

4. O'Flaherty J, Phillips C. The use of flipped classrooms in higher education: A scoping review. Internet High Educ [Internet]. 2015;25(February $2015): 85-95$. Available from: http://dx.doi.org/10.1016/j.iheduc.2015.02.002

5. Blackboard Inc. Educational benefits of online learning. www.blackboard.net [Internet]. $2000 ; 1-6$. A va i 1 a b 1 e from: http://blackboardsupport.calpoly.edu/content/fac ulty/handouts/Ben_Online.pdf

6. Mccutcheon K, Lohan M, Traynor M, Martin D. A systematic review evaluating the impact of online or blended learning vs. face-to-face learning of clinical skills in undergraduate nurse education. J Adv Nurs. 2015;71(2):255-70.

7. Sadeghi R, Sedaghat MM, Sha Ahmadi F. Comparison of the effect of lecture and blended teaching methods on students' learning and satisfaction. J Adv Med Educ Prof [Internet]. 2014;2(4):146-50. Available from: http://www.pubmedcentral.nih.gov/articlerender. fcgi artid $=4235559 \&$ tool $=$ pmcentrez\&rendertyp $\mathrm{e}=$ abstract

8. Balasubramaniam SM, Bhargava S, Agrawal N, Asif R, Chawngthu L, Sinha P, et al. Blending virtual with conventional learning to improve student midwifery skills in India. Nurse Educ Pract. 2018;28(October 2017):163-7.

9. Protsiv M, Rosales-Klintz S, Bwanga F, Zwarenstein M, Atkins S. Blended learning across universities in a South-North-South collaboration: A case study. Heal Res Policy Syst [Internet]. $2016 ; 14(1): 1-12$. Available from: http://dx.doi.org/10.1186/s12961-016-0136-x

10. Kaur M. Blended learning - its challenges and future. Procedia - Soc Behav Sci [Internet]. $2013 ; 93: 612-7$. Available from: http://linkinghub.elsevier.com/retrieve/pii/S1877 04281303351X

11. Nazarenko AL. Blended learning vs traditional learning: What works? (A Case study research). Procedia - Soc Behav Sci [Internet]. 2015;200(October):77-82. Available from: http://linkinghub.elsevier.com/retrieve/pii/S1877 042815046662

12. Güzer B, Caner H. The past, present and future of blended learning: An in depth analysis of literature. Procedia Soc Behav Sci [Internet]. 2014;214(1):4596-603. Available from: http://dx.doi.org/10.1016/j.sbspro.2014.01.992

13. Vaona A, Banzi R, Kh K, Rigon G, Cereda D, Pecoraro V, et al. E-learning for health professionals ( Review ). Cochrane Database Syst Rev. 2018;(1).

14. Kotoua S, Ilkan M, Kilic H. The growing of online education in Sub Saharan Africa: Case study Ghana. Procedia - Soc Behav Sci [Internet]. 2015;191:2406-11. Available from: http://linkinghub.elsevier.com/retrieve/pii/S1877 042815029377
15. Harerimana A, Mtshali NG, Hewing $H$, Kyamusoke EB, Mukankaka A, Gasurira S, et al. E-Learning in nursing education in Rwanda? Benefits and challenges. An Exploration of participants ' perceptives. J Nurs Heal Sci. 2016;5(2):64-92.

16. Liu Q, Peng W, Zhang F, Hu R, Li Y, Yan W. The effectiveness of blended learning in health professions: Systematic review and metaanalysis. J Med Internet Res. 2016;18(1):e2.

17. Li Z, Tsai M-H, Tao J, Lorentz C. Switching to blended learning: The impact on students' academic performance. J Nurs Educ Pract [Internet]. 2014;4(3):245-51. Available from: http://www.sciedu.ca/journal/index.php/jnep/arti cle/view/3477

18. Soper T. Knowledge into learning: comparing lecture, e-learning and self-study take-home packet instructional methodologies with nurses. Nurs Open [Internet]. 2017;4(2):76-83. Available from: http://doi.wiley.com/10.1002/nop2.73

19. Kenney J, Newcombe E. Adopting a blended learning approach: Challenges encountered and lessons learned in an action research study. J Asynchronous Learn Netw [Internet]. $2011 ; 15(1): 45-57$. Available from: http://dx.doi.org/10.1016/j.sbspro.2014.01.992

20. Mukama E. Baseline study of the status of opne and distance learning in Rwanda. 2016;38. Available from: www.col.org

21. Zolfaghari M, Negarandeh R, Eybpoosh S. Developing a blended learning program for nursing and midwifery students in Iran: Process and preliminary outcomes. Iran J Nurs Midwifery Res. 2013;18(1):20-6.

22. Eghbalibabadi M, Ashouri E. Comparison of the effects of two teaching methods on the nursing students ' performance in measurement of blood pressure. Iran J Nurs Midwifery Res [Internet]. $2014 ; 19(4): 3-7$. Available from: https://www.ncbi.nlm.nih.gov/pmc/articles/PMC 4145493/

23. Arksey H, O'Malley L. Scoping studies? Towards a methodological framework. Int $\mathrm{J}$ Soc Res Methodol. 2005;8(1):19-32.

24. Armstrong R, Hall BJ, Doyle J, Waters E. "Scoping the scope" of a cochrane review. J Public Health (Bangkok). 2011;33(1):147-50.

25. Levac D, Colquhoun H, O'Brien KK. Scoping studies: Advancing the methodology. Implement Sci. 2010;5(1):1-9.

26. Sweeney MR, Kirwan A, Kelly M, Corbally M, O Neill S, Kirwan M, et al. Transition to blended learning: experiences from the first year of our blended learning Bachelor of Nursing Studies programme. Contemp Nurse. 2016;52(5):612-24.

27. Young N, Randall J. The use of blended learning to create a module about ill-health during childbirth for pre-registration midwifery students. Nurse Educ Pract [Internet]. 2014;14(1):87-91. A v a i 1 a b 1 e $\mathrm{f} \mathrm{r}$ o $\mathrm{m}$ : http://dx.doi.org/10.1016/j.nepr.2013.02.016 
28. Mary S, Julie J, Jennifer G. Teaching evidence based practice and research through blended learning to undergraduate midwifery students from a practice based perspective. Nurse Educ Pract [Internet]. 2014;14(2):220-4. Available $\begin{array}{lllll}\mathrm{f} & \mathrm{r} & \mathrm{o} & \mathrm{m}\end{array}$ http://dx.doi.org/10.1016/j.nepr.2013.10.001

29. Mulaudzi FM, Chyun DA. Innovation in Nursing and Midwifery Education and Research. Rwanda Journa Ser F Med Heal Sci. 2015;2(2).

30. Harerimana A, Mtshali NG, Hewing $\mathrm{H}$, Kyamusoke EB, Mukankaka A, Gasurira S, et al. E-Learning in Nursing Education in Rwanda? Benefits and Challenges. An Exploration of Participants ' Perceptives. J Nurs Heal Sci. 2016;5(2):64-92.

31. Creedon SA, Cummins AM. Development of a blended model of teaching and learning for nursing students on rostered placement to ensure competence in information and communication technology for professional practice in Ireland. CIN - Comput Informatics Nurs. 2012;30(5):274-9.

32. Bergström P, Lindh V. Developing the role of Swedish advanced practice nurse (APN) through a blended learning master's program: Consequences of knowledge organisation. Nurse Educ Pract [Internet]. 2018;28(October 2017): 196-201. Available from: https://doi.org/10.1016/j.nepr.2017.10.030

33. Appiagyei M, Trump A, Danso E, Yeboah A, Searle S, Carr C. Case study: The role of elearning in midwifery pre-service education in Ghana. World Heal Popul [Internet]. 2015;16(2):54-61. Available from: https://www.longwoods.com/content/24492
34. Balasubramaniam SM, Bhargava S, Agrawal N, Asif R, Chawngthu L, Sinha P, et al. Blending virtual with conventional learning to improve student midwifery skills in India. Nurse Educ Pract [Internet]. 2018;28(November $2016): 163-7$. Available from: https://doi.org/10.1016/j.nepr.2017.10.028

35. Young N, Randall J. The use of blended learning to create a module about ill-health during childbirth for pre-registration midwifery students. Nurse Educ Pract. 2014;14(1):87-91.

36. Mulaudzi FM, Chyun DA. Innovation in nursing and midwifery education and research. Rwanda Journa Ser F Med Heal Sci. 2015;2(2).

37. Sweeney MR, Kirwan A, Kelly M, Corbally M, O Neill S, Kirwan M, et al. Transition to blended learning: experiences from the first year of our blended learning Bachelor of Nursing Studies programme. Contemp Nurse [Internet]. 2016;52(5):612-24. Available from: http://dx.doi.org/10.1080/10376178.2016.11977 81

38. Atef $\mathrm{H}$, Medhat $\mathrm{M}$. Blended learning possibilities in enhancing education, training and development in developing countries? A case study in graphic design courses. TEM J [Internet]. 2015;4(4):358-65. Available from: www.temjournal.com

39. Kumpu M, Atkins S, Zwarenstein M, Nkonki L. A partial economic evaluation of blended learning in teaching health research methods: A three-university collaboration in South Africa, Sweden, and Uganda. Glob Health Action. 2016;9(1):1-10

\section{How to cite this article:}

Ndayisenga, J.P., Babenko-Mould, Y., Kasine, Y., Nkurunziza, A., Mukamana, D., Murekezi, J., Tengera, O., Muhayimana, A. Blended teaching and learning methods in nursing and midwifery education: A scoping review of the literature. Research Journal of Health Science, 2021, 9(1): 100-114 
Table 1. Key Search words

Search Words

Blended learning

Sub-Saharan Africa

Africa

Rwanda

Nursing education

Midwifery education

Undergraduate education

Graduate education

Traditional classroom teaching

Face-to-face teaching and learning

E-learning

Online learning

\section{Search Limiters}

Written in English

Published between 2010-2019

Peer Reviewed

\section{Table 2. Inclusion and Exclusion Criteria}

\section{Inclusion Criteria}

Literature related to:

- Blended Learning or Online learning

- Hybrid Learning

- Mixed-mode Instruction

- Technology-mediated in Nursing and/or Midwifery education

Timeframe of 2010-2019

English Language

Presence of the Abstract

Both qualitative and quantitative studies.

\section{Exclusion Criteria}

Literature on Blended Learning in other disciplines

Timeframe older than 2010

Language other than English

Absence of abstract 


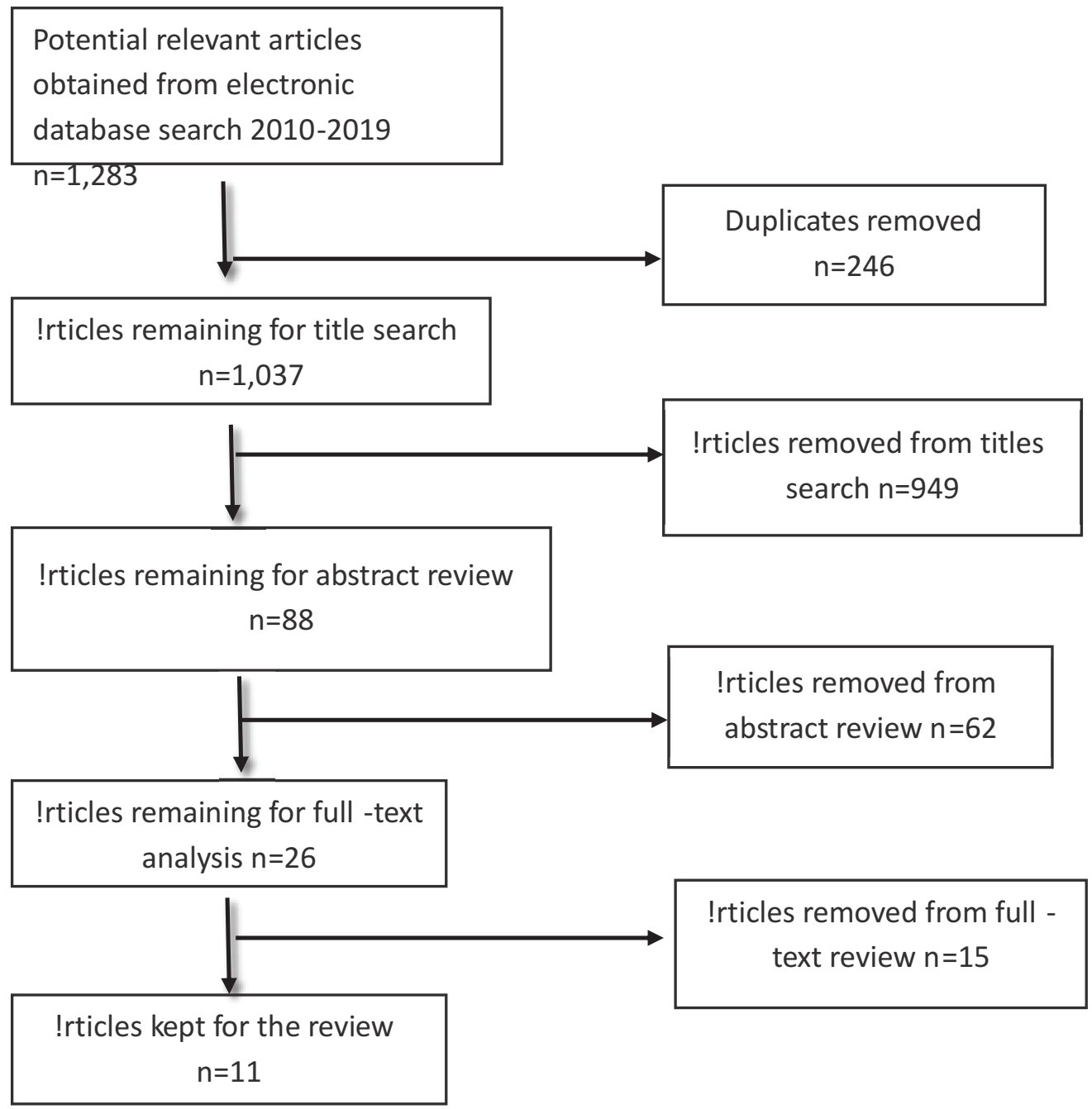

Figure 1.Flow diagram of scoping review process with inclusion and exclusion criteria of used articles 
Table 3a: Results

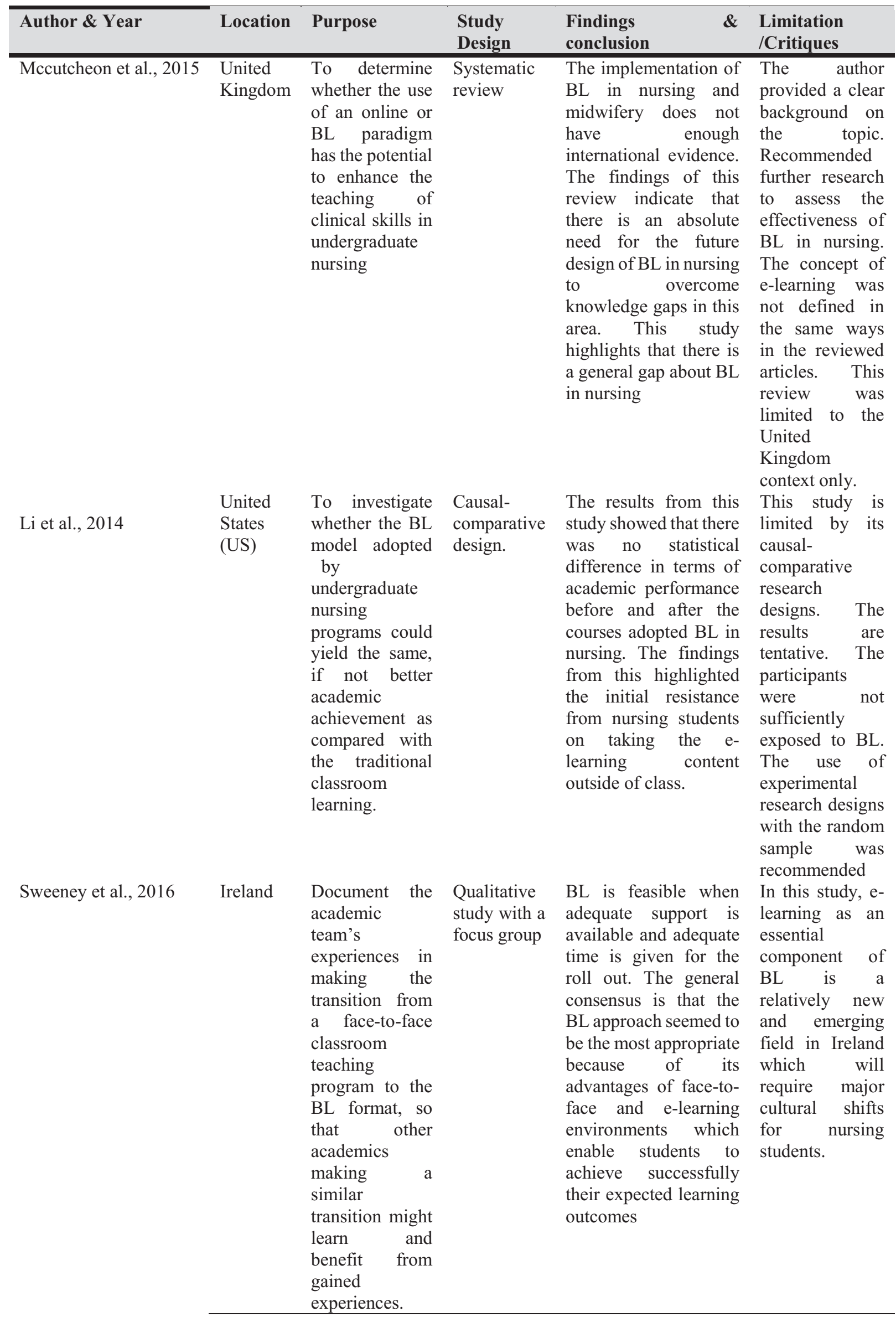


Table 3b: Results

\begin{tabular}{|c|c|c|c|c|c|}
\hline Author \& Year & Location & Purpose & $\begin{array}{l}\text { Study } \\
\text { Design }\end{array}$ & $\begin{array}{l}\text { Findings } \\
\text { conclusion }\end{array}$ & $\begin{array}{l}\text { Limitation } \\
\text { /Critiques }\end{array}$ \\
\hline Mary, Julie, \& Jennifer, 2014 & Australia & $\begin{array}{l}\text { Description of } \\
\text { the design, } \\
\text { delivery, and } \\
\text { evaluation of } \\
\text { an } \\
\text { undergraduate } \\
\text { Evidence- } \\
\text { based practice } \\
\text { and research } \\
\text { course } \\
\text { delivered in } \\
\text { the BL model } \\
\text { to first year } \\
\text { midwifery } \\
\text { students }\end{array}$ & $\begin{array}{l}\text { Qualitative } \\
\text { descriptive } \\
\text { study }\end{array}$ & $\begin{array}{l}\text { BL model enabled } \\
\text { midwifery students } \\
\text { to develop a good } \\
\text { relationship with } \\
\text { their peers and } \\
\text { lecturer within the } \\
\text { intensive workshops } \\
\text { and improved } \\
\text { students' } \\
\text { engagement in the } \\
\text { learning process. BL } \\
\text { improved students' } \\
\text { satisfaction about } \\
\text { created BL } \\
\text { environment and it } \\
\text { provides different } \\
\text { teaching and } \\
\text { learning } \\
\text { opportunities with } \\
\text { international } \\
\text { lecturers or experts. } \\
\text { BL can provide a } \\
\text { positive result in a } \\
\text { threshold } \\
\text { knowledge subject }\end{array}$ & $\begin{array}{l}\text { The author did } \\
\text { not describe } \\
\text { the used } \\
\text { methodology } \\
\text { in a clear way. } \\
\text { The module } \\
\text { was developed } \\
\text { in different } \\
\text { areas or } \\
\text { countries } \\
\text { (United } \\
\text { Kingdom) out } \\
\text { of the } \\
\text { implemented } \\
\text { country } \\
\text { (Australia). } \\
\text { This could } \\
\text { have some } \\
\text { significant } \\
\text { impact on } \\
\text { midwifery } \\
\text { culture and } \\
\text { context could } \\
\text { not be similar. } \\
\text { The content } \\
\text { and context } \\
\text { validation here } \\
\text { was necessary. }\end{array}$ \\
\hline Bergström \& Lindh, 2018 & Sweden & $\begin{array}{l}\text { Understand } \\
\text { how, from } \\
\text { students' } \\
\text { perspective, } \\
\text { the nurse } \\
\text { master's BL } \\
\text { program } \\
\text { structured } \\
\text { knowledge for } \\
\text { their future } \\
\text { position as } \\
\text { advanced } \\
\text { practice nurses } \\
\text { (APNs). }\end{array}$ & $\begin{array}{l}\text { Qualitative } \\
\text { study }\end{array}$ & $\begin{array}{l}\text { The findings of this } \\
\text { study highlighted } \\
\text { that though BL } \\
\text { methods, master's } \\
\text { students were able to } \\
\text { gain a more } \\
\text { advanced identity of } \\
\text { becoming APNs. } \\
\text { Students perceived } \\
\text { their positions as } \\
\text { nurses based on a } \\
\text { discourse of } \\
\text { knowledge in } \\
\text { relation to the } \\
\text { practical and } \\
\text { theoretical } \\
\text { knowledge, they } \\
\text { encountered in this } \\
\text { BL master's } \\
\text { program. }\end{array}$ & $\begin{array}{l}\text { The author } \\
\text { provided a } \\
\text { clear and } \\
\text { detailed } \\
\text { background } \\
\text { about BL in a } \\
\text { Swedish } \\
\text { context. The } \\
\text { author also } \\
\text { suggests that } \\
\text { BL model } \\
\text { could be used } \\
\text { to strengthen } \\
\text { APN as well as } \\
\text { the healthcare } \\
\text { system in } \\
\text { Sweden. }\end{array}$ \\
\hline Young \& Randall, 2014 & England & $\begin{array}{l}\text { To describe } \\
\text { different } \\
\text { teaching and } \\
\text { learning } \\
\text { methods } \\
\text { including } \\
\text { small groups } \\
\text { work, } \\
\text { traditional } \\
\text { discursive } \\
\text { lecturers, use }\end{array}$ & $\begin{array}{l}\text { Descriptive } \\
\text { study }\end{array}$ & $\begin{array}{l}\text { Midwifery students } \\
\text { who were involved } \\
\text { in this study with BL } \\
\text { had increased their } \\
\text { knowledge in } \\
\text { relation to } \\
\text { recognition of ill- } \\
\text { health and their } \\
\text { midwifery role. BL } \\
\text { provided more } \\
\text { learning }\end{array}$ & $\begin{array}{l}\text { BL approach } \\
\text { and innovation } \\
\text { were } \\
\text { recommended } \\
\text { as an effective } \\
\text { teaching and } \\
\text { learning } \\
\text { methods. In } \\
\text { addition, the } \\
\text { use of BL was } \\
\text { considered as a }\end{array}$ \\
\hline
\end{tabular}


Table 3c: Results

\begin{tabular}{|c|c|c|c|c|c|}
\hline Author \& Year Location & Purpose & $\begin{array}{l}\text { Study } \\
\text { Design }\end{array}$ & $\begin{array}{l}\text { Findings } \\
\text { conclusion }\end{array}$ & $\begin{array}{l}\text { Limitat } \\
\text { /Critiqu }\end{array}$ & \\
\hline Zolfaghari et al., 2013 & Iran & $\begin{array}{l}\text { To develop } \\
\text { and evaluate } \\
\text { outcomes of } \\
\text { BL program } \\
\text { for educating } \\
\text { nursing and } \\
\text { midwifery } \\
\text { students at } \\
\text { one } \\
\text { University in } \\
\text { Iran }\end{array}$ & $\begin{array}{l}\text { Mixed } \\
\text { methods } \\
\text { with } \\
\text { Participatory } \\
\text { action } \\
\text { research }\end{array}$ & $\begin{array}{l}\text { The students who } \\
\text { participated in BL } \\
\text { scored a higher GPA } \\
\text { than those who } \\
\text { participated in face- } \\
\text { to-face methods. } \\
\text { Educators who } \\
\text { participated in this } \\
\text { study appreciated } \\
\text { the BL approach as } \\
\text { one of the inevitable } \\
\text { educational } \\
\text { requirements of } \\
\text { nursing and } \\
\text { midwifery today. } \\
\text { BL was admired and } \\
\text { preferred by most of } \\
\text { the students }\end{array}$ & $\begin{array}{l}\text { The BL } \\
\text { program } \\
\text { showed a } \\
\text { positive effect } \\
\text { on students' } \\
\text { participation } \\
\text { and learning } \\
\text { outcomes. } \\
\text { However, the } \\
\text { researchers did } \\
\text { not control } \\
\text { other factors } \\
\text { such as virtual } \\
\text { learning } \\
\text { environment, } \\
\text { course design, } \\
\text { instructor's } \\
\text { role, used } \\
\text { pedagogy, and } \\
\text { instructional } \\
\text { design, and } \\
\text { course } \\
\text { outcomes } \\
\text { which can have } \\
\text { the effect on } \\
\text { program } \\
\text { outcomes. }\end{array}$ \\
\hline Balasubramaniam et al., 2018 & India & $\begin{array}{l}\text { Evaluation of } \\
\text { the } \\
\text { effectiveness } \\
\text { of } \\
\text { approach } \\
\text { model in } \\
\text { improving } \\
\text { identified key } \\
\text { midwifery } \\
\text { skills of } \\
\text { auxiliary } \\
\text { nurse } \\
\text { midwife } \\
\text { students in } \\
\text { low resource } \\
\text { settings }\end{array}$ & $\begin{array}{l}\text { Pre-and } \\
\text { post- } \\
\text { intervention } \\
\text { design } \\
\text { without a } \\
\text { control } \\
\text { group. }\end{array}$ & $\begin{array}{l}\text { BL approach } \\
\text { effectively } \\
\text { improved access to } \\
\text { quality training and } \\
\text { improved } \\
\text { professional skills } \\
\text { among auxiliary } \\
\text { nurse midwife } \\
\text { students from } \\
\text { remote locations. } \\
\text { This study } \\
\text { hypothesized that } \\
\text { the BL model will be } \\
\text { able to prepare more } \\
\text { competent and } \\
\text { confident nurse- } \\
\text { midwives for the } \\
\text { future. This study } \\
\text { concluded that BL } \\
\text { could be used for } \\
\text { improving } \\
\text { midwifery ar of } \\
\text { competencies } \\
\text { caring mothers and } \\
\text { infants of auxiliary } \\
\text { nurse midwives } \\
\text { from remote areas. }\end{array}$ & $\begin{array}{l}\text { The authors } \\
\text { provided a } \\
\text { clear } \\
\text { background of } \\
\text { this study. } \\
\text { Further } \\
\text { research is } \\
\text { needed to } \\
\text { evaluate the } \\
\text { cost-effective } \\
\text { and the } \\
\text { feasibility of } \\
\text { the is } \\
\text { interventions } \\
\text { before it is } \\
\text { scaled up. The } \\
\text { maternal and } \\
\text { neonatal health } \\
\text { outcome } \\
\text { expressed in } \\
\text { this study was } \\
\text { predicted not } \\
\text { measured as the } \\
\text { students were } \\
\text { not in direct } \\
\text { patients care } \\
\text { provision. }\end{array}$ \\
\hline
\end{tabular}


Table 3d: Results

\begin{tabular}{|c|c|c|c|c|c|}
\hline Author \& Year Location & Purpose & $\begin{array}{l}\text { Study } \\
\text { Desig }\end{array}$ & Findings $\&$ & $\begin{array}{ll}\text { conclusion } & \text { Limita } \\
& / \text { Critiq }\end{array}$ & \\
\hline Mulaudzi \& Chyun, 2015 & $\begin{array}{l}\text { South } \\
\text { Africa }\end{array}$ & $\begin{array}{l}\text { To discuss } \\
\text { innovation } \\
\text { initiatives: } \\
\text { BL, massive } \\
\text { open online } \\
\text { courses, } \\
\text { simulation, } \\
\text { and } \\
\text { embracing } \\
\text { technology in } \\
\text { a community- } \\
\text { oriented, } \\
\text { primary care } \\
\text { outreach } \\
\text { program } \\
\text { design }\end{array}$ & Issue Paper & $\begin{array}{l}\text { BL in nursing and } \\
\text { midwifery was } \\
\text { supported by the } \\
\text { literature as an } \\
\text { effective teaching } \\
\text { and learning } \\
\text { method which } \\
\text { promotes students' } \\
\text { innovative ideas } \\
\text { and critical } \\
\text { thinking. BL and } \\
\text { other innovation } \\
\text { initiatives like } \\
\text { massive open online } \\
\text { courses, simulation, } \\
\text { and use of } \\
\text { technology were } \\
\text { considered as } \\
\text { successful ways of } \\
\text { transforming } \\
\text { nursing education } \\
\text { and nursing care } \\
\text { delivery. }\end{array}$ & $\begin{array}{l}\text { The author did } \\
\text { not only focus } \\
\text { on BL but also } \\
\text { the discussion } \\
\text { was in broad } \\
\text { context of the } \\
\text { use technology } \\
\text { in nursing and } \\
\text { midwifery } \\
\text { education and } \\
\text { they based on } \\
\text { the authors } \\
\text { opinions. } \\
\text { Research studies } \\
\text { with specific } \\
\text { research } \\
\text { methodologies } \\
\text { are needed to } \\
\text { support the BL } \\
\text { and the use of } \\
\text { technology in } \\
\text { nursing and } \\
\text { midwifery } \\
\text { education and } \\
\text { research are } \\
\text { needed in this } \\
\text { area. }\end{array}$ \\
\hline Appiagyei et al., 2015 & Ghana & $\begin{array}{l}\text { Evaluation of } \\
\text { feasibility and } \\
\text { effectiveness } \\
\text { of both e- } \\
\text { learning in } \\
\text { conjugation } \\
\text { with face-to- } \\
\text { face } \\
\text { approaches } \\
\text { for midwifery } \\
\text { pre-service } \\
\text { education }\end{array}$ & $\begin{array}{l}\text { Mixed } \\
\text { Methods }\end{array}$ & $\begin{array}{l}\text { The findings of this } \\
\text { study indicated that } \\
\text { the used of e- } \\
\text { learning module in } \\
\text { midwifery is } \\
\text { feasible in terms of } \\
\text { accessibility, } \\
\text { accessibility, and } \\
\text { usability. }\end{array}$ & $\begin{array}{l}\text { This study used } \\
\text { a small number } \\
\text { of schools and } \\
\text { modules and } \\
\text { this can limit the } \\
\text { generalization } \\
\text { of this study's } \\
\text { findings }\end{array}$ \\
\hline Harerimana et al., 2016 & Rwanda & $\begin{array}{l}\text { Analysis of } \\
\text { the utilization } \\
\text { of e-learning } \\
\text { in the selected } \\
\text { nursing } \\
\text { campus in } \\
\text { Rwanda }\end{array}$ & $\begin{array}{l}\text { A convergent } \\
\text { mixed } \\
\text { method/ } \\
\text { Triangulation } \\
\text { design }\end{array}$ & $\begin{array}{l}\text { Emerging data } \\
\text { revealed that the } \\
\text { form BL used to } \\
\text { allow the } \\
\text { participants to be } \\
\text { more engaged } \\
\text { whether face-to- } \\
\text { face or via web- } \\
\text { based in Rwandan } \\
\text { context. The } \\
\text { participants } \\
\text { appreciated BL as a } \\
\text { flexible teaching } \\
\text { and learning } \\
\text { method. It was } \\
\text { reported also that } \\
\text { BL promotes the } \\
\text { use of innovating } \\
\text { and interactive } \\
\text { teaching methods. }\end{array}$ & $\begin{array}{l}\text { BL and e- } \\
\text { learning were } \\
\text { used } \\
\text { interchangeably. } \\
\text { There is the } \\
\text { inadequate } \\
\text { training of nurse } \\
\text { and midwife } \\
\text { educators in use } \\
\text { of BL. There are } \\
\text { no clear policies } \\
\text { regarding the } \\
\text { use of BL and } \\
\text { some educators } \\
\text { demonstrated } \\
\text { resistance to } \\
\text { change from } \\
\text { traditional } \\
\text { teaching to BL. } \\
\text { Proper training }\end{array}$ \\
\hline
\end{tabular}

